\title{
Professionalism of the built environment researcher
}

George Ofori

George Ofori

London South Bank University, UK

Corresponding author: George Ofori, oforig3Alsbu.ac.uk

https://doi.org/10.5592/CO/FTCE.2019.01

Scientific Symposium FUTURE TRENDS IN CIVIL ENGINEERING

Zagreb, Croatia, 17 October 2019 


\section{Professionalism of the built environment researcher}

\section{Abstract}

What is professionalism? How important is professionalism to any particular field of endeavour and to society as a whole? Does a researcher have to demonstrate professionalism? How is the professionalism of a researcher determined, and how is it assessed?

How important is professionalism to the field of research on the built environment? What form does professionalism among researchers on the built environment take? Who should develop the professionalism of such researchers? How should studies of professionalism in the field the built environment be done; what is the method to be applied in such studies? Who will be the gatekeeper of professionalism in that field, and who will undertake the assessment of the levels of professionalism?

The study is exploratory in nature. It seeks to address the questions outlined above on professionalism in the field of built environment research. It suggests that the community of researchers on the built environment should give professionalism greater attention. It recommends that further studies on the parameters of the area of research be undertaken and proposes some relevant topics.

Key words: professionalism, researchers, built environment, assessment framework, gatekeeper

\section{Profesionalnost istraživača u području građevinarstva}

\section{Sažetak}

Što je to profesionalnost? Kolika je njezina važnost u određenom području, ali i čitavom društvu? Treba li istraživač demonstrirati i profesionalnost? Kako se određuje profesionalnost istraživača i kako se ocjenjuje?

Koliko je važna profesionalnost kod istraživanja u izgrađenom okruženju? U kojem se obliku profesionalnost kod istraživača, u području izgrađenoga okruženja, pojavljuje? Tko bi trebao biti odgovoran za razvoj profesionalnosti takvih istraživača? Kako bi se trebale izrađivati studije o profesionalnosti u području izgrađenoga okruženja i koje bi se, pritom, metode trebale primjenjivati? Tko je osoba zadužena za očuvanje profesionalnosti u ovom području i tko bi trebao procjenjivati njezine razine?

Ovo je preliminarna studija koja pokušava odgovoriti na prethodno postavljena pitanja o profesionalnosti u istraživanju području izgrađenoga okruženja. Njezini rezultati pokazuju kako istraživačka zajednica u području izgrađenoga okruženja treba obraćati veću pažnju razvoju i očuvanju profesionalnosti. Studija poziva na daljnja istraživanja u području parametara područja istraživanja u izgrađenom okolišu te, pritom, predlaže važna daljnja istraživačka područja.

Ključne riječi: profesionalnost, istraživači, izgrađeno okruženje, okvir za procjenu, nadglednik 


\section{Introduction}

\subsection{Background}

In common usage, the word 'professionalism' is applied to relate to quality in the undertaking of tasks or delivery of services and the demonstration of expert knowledge. The term 'professionalism' is currently used to refer to elements of superior performance in business, public administration, the arts, sports and so on. Evans [I] suggests that the term appears in company mission statements, governments' policy documents, and in arguments on the merits of good practice, and best-in-class performance. The often highlighted attributes of professionalism include possessing specialised knowledge in a particular field, being competent in what the person does, demonstrating honesty, integrity and accountability, being reliable, showing selfregulation, and being worthy of respect and trust by society [2, 3].

How a professional attains and demonstrates competence differs from one field to another, and in some cases, this is particularly stated in, and enforced, through regulations or statutory codes of practice. It is also suggested that the meaning of 'professionalism' also varies for different people and different organisations. Moreover, as Gavett [4] notes, while definitive research-based evidence is not available, the ways in which people evaluate professionalism varies from one country to another.

Research on the field of the built environment has a major role to play in improving performance in construction industry and the segments of the economy related to it. Such improvements are essential owing to the role the physical items created play in the economy and the benefits they bring to societies.

For the purpose of this study, the term "built environment" is used to refer to the various types of buildings, infrastructure and other structures as well as the related ancillary facilities which are necessary for production, social activity and upliftment of lives. The "built environment sector" is the part of the economy comprising the entities and persons who are involved in all aspects of the activities which result in the creation, operation and maintenance and eventual demolition of the items which constitute the built environment.

It is widely acknowledged that the level of professionalism in the built environment leaves much to be desired. For example, challenges facing the UK built environment professions, identified by The Edge Commission which relate to the state of professionalism include [5]:A Performance Gap; Lack of Attention to Climate change; Loss of public trust; Siloed education; Growing scepticism of younger professionals; Proliferation of 'professions'; and Low level of member engagement. Ofori and Ceric [6] relate the features of the construction industry, construction process and constructed product to the implications for professionalism and the importance of trust. They show that the client-industry relationship in the UK's built environment sector is generally based on mutual suspicion and "risk-passing". 
Reflecting on his tenure as Chief Executive of the Chartered Institute of Building, Chris Blythe [7] notes the "drive to the bottom" in the industry and suggests that the industry's practices have an adverse impact on the performance on projects and thus that of companies; in turn, it reflects poorly on its image. He suggested [7]: "We've educated a generation to think that beating up the subcontractor is being professional. Which is shameful.....'. It would appear that the industry has not proved itself worthy of the public's trust [5, 8]. For example, in the UK, [7] notes that: "Industry selfregulation and the culture it created will end. It is getting to be indefensible, because of events like Grenfell and Carillion's collapse".

\subsection{Aim and objectives}

The aim of the study is to examine the importance of professionalism in research in the field of the built environment and how its level can be assessed, with the view to enhancing it. The objectives of the study are to:

I) establish the importance of the built environment to any economy and society

2) consider the nature and features of professionalism and its importance in all fields of activity

3) explore the relevance of professionalism in research

4) study the level of professionalism among the researchers on the field of the built environment

5) propose an analytical framework for assessing professionalism among built environment researchers, and suggest courses of action to enhance professionalism among the researchers.

\section{Built environment research}

\subsection{Need for research in the built environment}

The built environment is both special and peculiar. It establishes the physical framework for both productive and social activities in any country. The built environment enables economic growth and long-term social development of nations, and the enhancement of the quality of life of their citizenry [9]. The sector of the economy which produces the built environment should perform at the top level of its efficiency and effectiveness, and contribute to the enhancement of performance in all the sectors of the economy which rely on it. Research has a role to play in:

a) investigating, and finding possible solutions to, the weaknesses of the sector which produces and manages the built environment and its component entities;

b) studying the materials, technologies and processes it builds with;

c) understanding the items it builds and their performance over time; proposing solutions to its challenges;

d) suggesting ways and means for the continuous development of the sector and innovation within it. 
In contemporary times, the issues of productivity, affordability and sustainable development are particularly pertinent. Productivity is now well recognised to be at the centre of economic growth [9], and the built environment sector is expected to make its contribution. Affordable housing is a consideration in countries at all levels of development. The built environment sector and its performance play a key role in the determination of the costs and hence, affordability of built items. The built environment is also a major user of the earth's non-renewable resources and a significant contributor to carbon emissions [10]. Researchers have a responsibility to develop the knowledge required to minimise these impacts. There is also the issue of the impact of climate change and environmental degradation on the existing built environment.

\subsection{Characteristics of built environment and its sector, and need for improvement}

The features of the built environment sector establish its uniqueness; there is a need to understand the underlying factors of these features, and to take action to improve aspects of the sector and enhance its performance. The features include [ II, I2, I3]: the large size and significant contribution of the sector to the economy as well as the backward and forward linkage effects; the high expense and long period of gestation of each project; the labour generation potential of building work; the large number of distinct activities and participants in each project; the importance of the government as a client as well as a facilitator; and the array of regulations which the built environment sector has to operate under.

The interdependence of the activities which are undertaken on any project in an atmosphere of uncertainty, leads to high levels of risks [14]. World Economic Forum and Boston Consulting Group show how the practices of the construction industry draw directly from the attitudes, demands and expectations of the industry's risk averse clients [15]. Similar influences on the way the built environment sector works can be traced to regulation, government policies and/or the aspects of the operating context of the sector, including the stakeholders and business partners of the sector. In general, these various influences on the built environment sector and the responses the constituents of the sector have developed to them, have led to the emergence of a sector which performs poorly in most countries. For example, Millett [16] notes that research by the Mace group has shown that by 2030 , the world would be paying GBPI.2 trillion a year for projects which have not been delivered effectively. He notes that "it is down to the participants in the industry...".

Efforts have been made in many countries to improve the performance of the built environment sector. For example, Designing Buildings Wiki [17] presents a list of more than 90 reports on strategic reviews of the construction industry in the UK since 1934, the latest of which include the Construction 2025 strategy [18]; Farmer Review [19]; and Construction Sector Deal [9]. In many countries, much more needs to be done. Moreover, it would appear that what has been done seems to 
have been ineffective. Smith [20] noted that considerable attention has been given to projects over the years, mainly through government-commissioned reports on the UK contracting industry, yet the outcomes have fallen short of the hopes set out. He suggests that the causes of any shortfall may not completely reside at the project level; some of the reasons rest with the firms and their management [20]. Discussing the strategic reviews of the UK construction industry, Green challenges the construction improvement debate in the UK and suggests that the solutions proposed seldom stand up to critical scrutiny [2I]. For example, usually accepted approaches to improvement such as lean construction, partnering and collaborative working rarely live up to the claims made on their behalf. He argues that construction sector improvement techniques must also resonate with broader agendas of sociotechnological change [2I].

It is evident that attaining broad and sustained improvements in the performance of the built environment sector is a hard task. Construction Leadership Council [22] outlines a long list of actions by the UK government to realise improvements in the UK construction industry including those to improve regulations, tackle payments and settle disputes. It then presents a profile of the industry which shows that it still has all the undesirable factors and features, including those relating to payments [22]. Millett [16] notes that, in the UK: "Report after report has made it clear that unless we work together more effectively, we're going to face the same problems around forecasting, planning, and delivery. When a report is published, everyone agrees: we must work better together. However, when it comes down to it -- when the bottom line is at stake -- almost everyone in the industry ends up reverting to the "bad old days". Sweet notes that modernising construction is a tough task. "For various reasons, despite long-running improvement agendas in most of the world's most developed markets, construction remains a wasteful, tradition-bound industry plagued by delays, cost overruns, and contractual disputes" [23].

Researchers can contribute to the effort to find the best ways to ease bottlenecks in the sector and its processes, practices and regulations for creating and maintaining the built environment. Their work can provide the basis for measures by government and industry as well as other stakeholders to enhance performance in the value chains of the projects.

\subsection{Areas of research in built environment}

In considering the nature and extent of research on the built environment, it is useful to discuss the typology suggested by the International Council for Research and Innovation in Building and Construction [24]. It outlines the scope of its current commissions and suggests that they can be placed in these "areas of scientific interest":

a) General - broad aspects of research, education, innovation, information, regulation;

b) Building Technique - Construction Materials and Technologies, Building Physics; 
c) Buildings and the Environment - Design of Buildings, Built Environment;

d) Building Process - Management Organisation Economics, Legal and Procurement

Practices. The CIB notes that each of its commissions is different, according to its members' needs for international exchange and collaboration and the complexity of the topics on which they are engaged.

The broad areas of built environment research are outlined in the descriptors of the UK Research Excellence Framework (REF) 202I on Unit of Assessment 13: Architecture, Built Environment and Planning [25] which [26]: "covers all forms of historical, theoretical, technical, policy, applied and practice-based research relevant to the planning, design, creation, functionality, use, conservation, interpretation, assessment, management and governance of the built environment in both rural and urban areas. This includes: architecture and related arts, building engineering, building surveying, building sciences, climate change and disaster resilience, communities, construction, construction management, economic development, environment, health and well-being, housing, landscape, manufacture, natural resources and ecosystem services, real estate, regeneration, spatial analysis, sustainability, transport, urban and regional planning and urbanism. It covers the social, economic, legal, financial, environmental, technological, historic and cultural aspects of the built environment". The field of study of the built environment is wide, in terms of the range of subjects and areas of expertise it covers.

\section{Assessing research}

The researcher has to meet requirements and expectations which relate to the effort to obtain research inputs, to gather the necessary information and to find appropriate outlets for sharing the findings from the researcher's work. The definitions of quality of research and the areas to be considered differ from one field to another. There are also many gatekeepers, from journal editors through grant giving agencies and university promotion committees, to the researcher's own peers acting as reviewers for various purposes. The periodic review of the research performance of institutions in some countries (such as the UK's REF and Hong Kong's Research Assessment Exercise) are other assessment mechanisms. In terms of work produced, REF is intended to "assess the quality of submitted research outputs in terms of their 'originality, significance and rigour' with reference to international research quality standards" [26, pp. 7]. The impact is defined as: "'reach and significance' of impacts on the economy, society, culture, public policy or services, health, the environment or quality of life that were underpinned by excellent research conducted in the unit" [26, pp. 7].

There are a number of suggestions on the criteria for assessing research although these are not usually presented as being for that purpose. US National Research 
Council [27] identified six guiding principles for scientific research: Pose significant questions that can be investigated empirically; Link research to relevant theory; Use methods that permit direct investigation of the question; Provide a coherent and explicit chain of reasoning; Replicate and generalise across studies; and Disclose research to encourage professional scrutiny and critique.

Concepts such as "research integrity" and "responsible conduct of research" are also used. Korenman [28] notes that research integrity is essential for achieving scientific excellence and for earning the public's trust. Integrity embodies a scientist's commitment to intellectual honesty and personal responsibility and an institution's commitment to maintaining an environment that promotes responsible conduct. Thus, it is the active adherence to the ethical principles and professional standards essential for the responsible practice of research. Korenman presents these components of Responsible Conduct of Research [28]: Social responsibility; Performance; Reporting; Mentoring; Communication; and Conflicts of interest.

The assessment criteria for research differ from one field to another, as even if the same broad criteria are applied, different levels of weightage might be assigned to the same aspects from one field to the next. Moreover, the criteria also change over time. For example, increasingly, meaningful assessments of research include consideration of the relevance and impact of the work on industry and society. It is pertinent to note that the component of impact in the UK REF has increased (from 20 percent in REF20I 4 to 25 percent in REF202I) [26].

How effective have the assessment exercises been? The effectiveness can be considered in terms of the 'accuracy' of the assessment. For example, Lansley [29] indicates that analyses of the results of the RAEs in 1996 and 2001 supported the hypothesis that the grade awarded to a university department can be related to its level of activity in terms of, for example, number of research students, research studentships secured, research degrees awarded, research funded from external sources, and the profile of publications. Another way of viewing the effectiveness of the assessment would be in terms of the possible consequences of the results for the institutions and researchers. The former can be determined from the efforts universities make to prepare their submissions for the exercises. On the latter, Lansley [30] noted that, for many academics in UK universities, the nature and orientation of their research is determined by considerations of how that work will be graded in research assessment exercises (RAEs) because the grades awarded to particular work can have a significant impact on the career development of the individual, and the university.

There can be some conflict or tension between the assessment criteria and what would benefit society. For example, the REF criteria for research assessment determine quality by the appropriate indicators of:'originality','rigour' and 'significance'. However, these criteria might be detrimental to the development of the body of knowledge 
on the Built Environment. For example, the relevance of books as research output might be downplayed. This will draw the best researchers away from the authoring of critical references and textbooks for developing the next generation of practitioners and researchers on the field.

\section{Professionalism in research}

\subsection{What is professionalism?}

There is a large body of literature on the professions, the process of professionalisation and the concept of professionalism. This study focuses on professionalism.

Despite the long history of research on the 'professions' (see, for example, [3 I, 32]), Kolsaker [33, pp. 5I5-5I6] notes that the concept of professionalism is relatively under-researched, and the existing research is "criticised as ambiguous and lacking a solid theoretical foundation". Thus, it is difficult to definitively identify its constitution and characteristics. Professionalism is variously presented as: a form of occupational control; a socially constructed and dynamic entity; the application of knowledge to specific cases; the use of knowledge as social capital; a normative values system; the basis of the relationship between professionals and their publics; and a basis and determinant of social and professional status. The American Physical Therapy Association defines professionalism in that field as: "Physical therapists consistently demonstrate core values by aspiring to and wisely applying principles of altruism, excellence, caring, ethics, respect, communication and accountability, and by working together with other professionals to achieve optimal health and wellness in individuals and communities" [34].

Two other conceptualisations of professionalism may also be considered here. The American Pharmaceutical Association Task Force on Professionalism suggested that one acts professionally when one displays these ten traits [35]:

a) accountability for one's actions;

b) commitment to self-improvement of skills and knowledge;

c) conscience and trustworthiness;

d) a covenantal relationship with the client;

e) creativity and innovation;

f) ethically sound decision-making;

g) knowledge and skills of the profession;

h) leadership;

i) pride in the profession;

j) service orientation. 
In 200I, the American Board of Internal Medicine also proposed that the elements of professionalism are [36]:

a) commitment to the highest standards of excellence in practice and in the generation and dissemination of knowledge;

b) sustaining of the interest and welfare of clients; and

c) being responsive to the needs of society.

To fulfil these three elements, one must have these six tenets:

I) altruism;

2) accountability;

3) excellence;

4) duty;

5) honour and integrity;

6) respect for others.

These traits and elements are widely used in education, training and research. It is pertinent to note that the ten traits in the first concept are similar to the elements and their results in the second.

From the literature-based discussion above, it can be inferred that being professional is practising and living according to the standards, requirements and expectations of one's profession, one's stakeholders and the regulators (statutory agencies or professional institutions) of the field of activity. It is pertinent to note that what counts as acting professionally keeps shifting. Professionalism can be considered as a set of dispositions that result in one doing the best or seeking the best outcomes in undertaking one's tasks; taking ownership of the outcomes of one's work; and actively seeking improvements in those outcomes and possibly in the outcomes of the work of one's colleagues. It is pertinent to note the dynamism in many of the elements of the concept of professionalism. For example, the American Board of Internal Medicine [37] notes that the definition of medical professionalism today is evolving - from autonomy to accountability, from expert opinion to evidence-based medicine, and from self-interest to teamwork and shared responsibility.

Some countries have formulated strategies to enhance professionalism in the built environment sector. For example, Singapore's Construction 21 strategy included "Enhancing Professionalism" among the six strategic thrusts of the drive towards realising the vision for the construction industry: "To be A World Class Builder in The Knowledge Age" [38]. Malaysia's "Construction Industry Transformation Programme 2016-20" has four strategic thrusts [39]: Quality, Safety and Professionalism; Environmental Sustainability; Productivity; and Internationalisation. 


\subsection{Professionalism in the academic field}

There is a growing literature on professionalism in the academic field [40]. Orringer [4I] poses a number of questions including: What distinguishes professionalism in academics from that in other activities? Is it sufficient to rely on the praise for the nobleness of academics which is commonly conferred, participation in professional societies, undertaking research and publishing as much as one can; or attaining high administrative positions in academic institutions? In the responses to those questions, it is suggested that "academic professionalism" could cover what academics do in their professional and personal lives and how they do it; how they acquire their academic expertise and practice including the values they have and share with others; what purposes and services they provide to the community at large; and the relations they enjoy with colleagues worldwide. Thus, Evans presents academic 'professionalism' as work practice that is consistent with commonly-held consensual delineations of a specific profession or occupation and that contributes to and reflects perceptions of the profession's purpose and status and the nature, range and levels of service provided by, and expertise prevalent within, the profession, as well as the ethical code underpinning this practice $[\mathrm{I}]$.

Some academics hold negative views on academic professionalism and consider it to be losing its autonomy and status; others are more positive, suggesting that this is the time to redefine the term [40].

The research to date has not resolved the issue of how to conceptualise professionalism in the academic field.To Evans [I], this makes it difficult to appreciate how it functions and, therefore, how it may be influenced and enhanced. In particular, it might be difficult to understand professionalism among researchers. Contexts among universities and in the positions and disciplines of academics differ. Kolsaker [33] examines the impact of the managerialist approaches present in many universities' governance systems on academic professionalism. This approach is different from the collegial ideology that is characterised by self-management and self-direction. Universities do not have a common approach to policy, employment contracts and structured annual reviews as well as criteria for promotion which might dictate professional outcomes. For example, depending on the funding model, culture and tradition, teaching, the battle for student numbers and industry linkages may take precedence over research and other activities. There could be administrative pressures to produce volumes of work, or to target journals with certain metrics.

Callaway [42] notes that, to Kolsaker [33, pp. 5I6], key characteristics of the academic profession are "shared values, altruistic concern for students, educational expertise, high level of autonomy, generation of new knowledge, application of logic, use of evidence, conceptual and theoretical rigor and the disinterested pursuit of truth". He also suggests that the definition raises the questions of how one should relate to those who are not considered to be serving proper academic goals; and whether an 
academic professional has an obligation to avoid or question practices which appear not to be serving "the disinterested pursuit of truth".

It has been suggested that academics should have a statutory governing organisation to formulate and administer their own professional code of conduct as they have responsibility in moulding the minds and ways of thinking of the leaders of tomorrow [4I].While many members of the profession would not welcome such an impediment to academic freedom, it could be argued that, as the researchers on the built environment work on the knowledge which will enhance the performance of the nation's assets which have such possible impact on health and safety, professionalism is key, and ways of ensuring and enhancing it should be found.

The study focuses on research.

\subsection{Professionalism in research}

Professionalism means serving others responsibly by self-consciously working hard to attain high productivity and being aware of how to measure this productivity and make a difference in the world. An example of a group striving to serve others is the Inter Academy Partnership which noted that effective implementation of the UN Sustainable Development Goals (SDGs) "requires access to, and the application of, the best available evidence from the global community of knowledge providers" [43, Pp. 4]. It suggests urgent challenges which the global science community must address:

I) to ensure research and research support systems, including assessment and reward structures, better align with shared global goals;

2) to improve understanding of the interactions between SDGs (synergies and trade-offs) to multiply the positive impact of specific policy interventions;

3) to prioritise the development of improved indicators, to monitor progress on implementation more accurately;

4) to account for the implications of complex systems science, including how the SDGs can be delivered within the Earth's finite capacity and planetary boundaries.

Korenman [44] identified these elements of professionalism in scientific research: Intellectual honesty; Excellence in thinking and doing; Collegiality and openness; Autonomy and responsibility; and Self-regulation. However, on productivity in research, while input is easy to evaluate, in research output is less easy to estimate. There are various metrics: number of publications and various measures of impact of these metrics, but each of them can be disputed.

To summarise the discussion on professionalism in research, it is pertinent to paraphrase Korenman [44]:

Professionalism in science denotes a pattern of behaviour identified with scientific integrity that, in turn, provides certain privileges. Scientists are expected to behave with intellectual honesty and excellence in thinking and doing. In many 
respects they perform their professional activities as a monopoly, licensed by society. Professionals are supposed to behave collegially and teach the skills to others, and put society's needs first in their professional activity. In response, society gives them a great deal of autonomy in conducting their professional lives. With scientists, that means selection of one's own research problems and methods of procedure. They also are given the responsibilities to allocate funding, and review of their output in publications. Like other professions they are given responsibility for discipline in the event of poor performance or malfeasance. When self-regulation fails to sustain honesty and high quality, society imposes rules and laws to maintain its interests in professional quality.

\subsection{Importance of professionalism in built environment research}

Professionalism is important in the field of the built environment. In all countries, there is strict determination of the competence of many of the professionals in the field before the persons are permitted to practice. Moreover, the work done at the design stage must be submitted for approval, and some of the key aspects of site construction are subject to statutory inspection. This makes it pertinent for aspects of the field of the built environment to be the subject of research, with the view to devising better ways of practice.

The built items are expensive, take a long time to complete, and have complex relationships with their environment. It is unlikely that much of the work done on one project and the conditions and contexts encountered on that project would be replicated on other on other projects owing to differences in client requirements, governing regulations, specifications, practices, procedures and overall context.

Foxell [45] discusses the relationship between society, the economic system and professionalism in the built environment. He covers the changing responsibilities of professionals and, in particular, their obligation to act in the wider public interest. He presents a plan to help the professions to remain an effective and essential part of society and the economy; a part that allows the system to operate smoothly, fairly and to the benefit of all. Such considerations should also apply to built environment researchers. There is the potential for the researchers to work with the professions in the built environment sector, and with the government to create the body of knowledge proposed by The Edge Commission [5].

\subsection{Professionalism in built environment research: a framework for assessment}

What does society want from built environment researchers? To use their knowledge to improve the quality of life of the citizens. A recent study in the UK found that the industry does not have much use for the research done and, at the same time, does not have much of its challenges being investigated [46]. Thus, while the volume 
of research output and arguably its quality, has been increasing, this work is largely of no value. The US National Institute of Environmental Health Sciences (NIEHS) [47] states that it "strives to conduct and support the very best environmental health sciences in alignment with real-world public health needs, and to translate science findings into knowledge that can inform real-life individual and public health outcomes. Success in our mission requires the highest standards of stewardship, and a solid foundation of supportive strategies, resources, and training". There is a need to consider contribution to practice in research work in a systematic manner.

Some of the principles and criteria used to assess research are discussed above. The nature of the work of the sector which creates the built environment, the processes and inputs it uses, and the products it creates means that the ethics of the built environment researcher should be wider and deeper than any of the frameworks and parameters outlined above. It is necessary for an appropriate framework to be established.A tentative framework, based on the foregoing discussion on professionalism, is now proposed.

What attributes must a built environment researcher show in order to be considered to be professional? A possible framework is now discussed.

I) Social responsibility: the researcher should be committed to contributing to the progress and well-being of the community. The researcher should continually ask: "What am I doing to help create the most appropriate built environment for my country and the world?"

2) Intellectual honesty: while honesty is important for all researchers, it is even more so for work on the built environment because much of the research on aspects of the built environment is non-replicable; the projects and built items studied are widely dispersed even in the same country; context has an influence on possible results from the studies; and the accuracy of the results which are released is critical as it can have life and death consequences.

3) Excellence, creativity and innovation in thinking and doing: all researchers should be creative, seek to innovate and aim for excellence. In those working in the field of the built environment, this is even more necessary as many of the subjects are complex and innovation and the pursuit of excellence are required to find real solutions to some of the challenges in the industry which remain intractable.

4) Collegiality and openness: most of the aspects of the built environment involve the combination of a range of subject areas; multi-disciplinary studies are more needed here. Transparency is another necessary attribute where the built environment is concerned, again considering the possible life and death or at least socio-economic progress implications of its products, methods and inputs.

5) Autonomy, responsibility and accountability for one's actions: the researcher might be collaborating with others in doing the work, and might obtain support from a number of sources -- supervisors, colleagues, peer reviewers -- but the researcher has to take responsibility for, and ownership of, the work, and be able to defend it. 
6) Commitment to self-improvement of skills and knowledge: dedication to continuous improvement should be a major feature of all researchers, as every field changes over time.Also, commitment to further development of the field, to enable it to contribute more to society and enhance its place in the community of researchers and in society.

7) Conscience and trustworthiness: trust is an essential but rather scarce commodity within the built environment sector and between it and its stakeholders [6]. Researchers should maintain the trust of both groups: their counterparts and society.

8) Ethically sound decision making: the possible impact of the results of built environment research on health, safety, well-being and on the resulting product makes ethics a major consideration for the researcher.

9) Altruism: the researcher should have a higher calling than the possible direct benefit from the work being produced. The interest of society should be paramount.

10) Honour and integrity: it is difficult to replicate, or verify the results of most nontechnical built environment research because of uniqueness of contexts.

The field of built environment research needs a gate keeper. The groupings of researchers such as the $\mathrm{CIB}$ and Association of Researchers in Construction Management (ARCOM) or the 'faculties' within the professional institutions, could be considered to be potential gatekeepers. However, a multi-disciplinary and global organisation would be required.There is the need for consolidation and collaboration among the professions, and among government, industry and research, for example, to identify relevant research topics, to disseminate research findings, to monitor the implementation of these findings, and to propose follow-up action.

\section{Concluding remarks and recommendations}

Professionalism has much to do with responsibility and self-transcendence. Professionals should not call themselves such; it should be a 'title' bestowed on them by their peers and partners, and by society. Stark [48] suggests that professionalism has less to do with the results one produces, and much more to do with how one produces those results. Chris Blythe [7] suggests that:"Being professional is not about having letters after your name; it's the consequences of what you're doing”.

Professionalism is also about leadership. Among the nine criteria for a group to be considered a profession proposed by Lord Benson [49] is that: "In its specific field of learning, a profession must give leadership to the public it serves". The built environment researchers should seek to influence the pursuit of development of professionalism in the built environment. For example, Ofori and Ceric [6] suggest that greater professionalism and trust will reduce the need for regulation and administrative control of the building process and the product. 
Each built environment researcher should ask these questions:

a) Are we being professional when we continue to do work which the practitioners in the sector have no use for?

b) Should we accept any part of the blame for the poor performance of the built environment sector?

c) How can we play a role as responsible and professional researchers?

\section{References}

[I] Evans, L: Professionalism, professionality and the development of education professionals, British Journal of Educational Studies, 56 (2008) I, pp. 20-38.

[2] Romme, G.: The Quest for Professionalism: The case of management and entrepreneurship, Oxford University Press, Oxford, 2016.

[3] Stern, D.T.: Measuring Medical Professionalism, Oxford University Press, New York, 2006.

[4] Gavett, G.:What does professionalism look like? Harvard Business Review, 20 March 20I4, https://hbr. org/2014/03/what-does-professionalism-look-like.

[5] Morrell, P. (Ed.): The Edge Commission Report on the Future of Professionalism: Collaboration for Change, The Edge, London, 2015.

[6] Ofori, G., Cerić, A.: A new professionalism in construction: importance of trust, Proceedings of the International Conference on Professionalism and Ethics in Construction, London, 21-22 November, pp. 422-432, 2018.

[7] Mann, W.: 'It's been immense fun -- I have massive respect for the members', Construction Manager, May (2019), pp. 16-18.

[8] Spada: British Professions Today: the state of the sector, Chartered Institute of Management Accountants, Law Society, Royal Institution of Chartered Surveyors, London, 2009.

[9] HM Government: Industrial Strategy: Construction Sector Deal, London, 2018.

[10] Graham, P., Rawal, R.:Achieving the $2^{\circ} \mathrm{C}$ goal: the potential of India's building sector, Building Research and Information, 47 (2019) I, Pp. 108-122.

[II] Turin, D.A.:What do we mean by building, Habitat International, 5 (I980) 3, pp. 27I-288.

[12] Ofori, G.:The Construction Industry:Aspects of its economics and management, Singapore University Press, Singapore, 1990.

[13] Hillebrandt, P.M.: Economic Theory and the Construction Industry, Macmillan, London, 2000.

[14] Higgin, G., Jessop, N.: Communications in the Building Industry: The report of a pilot study, Tavistock Press, London, 2008.

[15] World Economic Forum and Boston Consulting Group: Shaping the Future of Construction, 20I5, https://www.weforum.org/global-challenges/projects/future-of-construction.

[16] Millett, J.: It's time to walk the talk on collaboration, Construction Manager, May (20I9), pp. 2 I.

[17] Designing Buildings Wiki : Construction Industry Reports, 2019. https://www.designingbuildings.co.uk/ wiki/Construction_industry_reports. 
[18] HM Government: Construction 2025: Joint strategy from government and industry for the future of the UK construction industry, London, 2013.

[19] Farmer, M.: Modernise or Die:Time to decide the industry's future - The Farmer Review of the UK Construction Labour Model, Construction Leadership Council, London, 2016.

[20] Smith, H.: Castles in the Air? The evolution of British main contractors, The Bartlett School of Construction and Project Management University College, London, 2018.

[2I] Green, S.: Making Sense of Construction Improvement, Wiley-Blackwell, Chichester, 201 I.

[22] Construction Leadership Council: Procuring for Value - Outcome based, transparent and efficient, London, 2018.

[23] Sweet, R.: How Singapore plans to push its construction industry into the 2 Ist Century, Global Construction Review, I4 October 20I4, http://www.globalconstructionreview.com/markets/howsingap98ore-pla37ns-pu90sh-it0s-constru36ction/.

[24] CIB: CIB Commissions' Scopes, 2019, https://www.cibworld.nl/site/about_cib/activities.html.

[25] UKRI: Research Excellence Framework 202I: Panel criteria and working methods, London, 2019.

[26] Department for the Economy, Higher Education Funding Council for Wales, Research England and Scottish Funding Council: REF202I Research Excellence Framework: Guidance on submissions, Bristol, 2019.

[27] National Research Council (NRC): Scientific Research in Education, The National Academies Press, Washington, D.C., 2002.

[28] Korenman, S.: Responsible Conduct of Research Involving Humans, undated, https://www.ctsi.ucla. edu/education/files/training/docs/responsible-conduct-korenman.pdf.

[29] Lansley, P.: Research assessment and the activity hypothesis, Engineering, Construction and Architectural Management, 20 (2013) I, pp. 7-28.

[30] Lansley, P.: Making sense of research quality assessment, Engineering, Construction and Architectural Management, 14 (2007) I, pp. 7-25.

[3I] Abbott,A.:The System of Professions:An essay on the division of expert labour, University of Chicago Press, Chicago, IL, 1988.

[32] Carr-Saunders, A.M.,Wilson, P.A.:The Professions, Clarendon Press, Oxford, 1933.

[33] Kolsaker,A.:Academic professionalism in the managerialist era: a study of English universities, Studies in Higher Education, 33 (2008) 5, pp. 513-525.

[34] American Physical Therapy Association: Professionalism for the physical therapist, 2019, http://www. apta.org/Professionalism/.

[35] American Pharmaceutical Association Academy of Students of Pharmacy and American Association of Colleges of Pharmacy Council of Deans Task Force on Professionalism: White Paper on Pharmacy Student Professionalism, Journal of the American Pharmaceutical Association, 40 (2000) I, pp. 96- 102.

[36] Robins, L., Braddock, C., Fryer-Edwards, K.:Using the American Board of Internal Medicine's “Elements of Professionalism" for undergraduate ethics education, Academic Medicine, 77 (2002) 6, pp. 523531.

[37] American Board of Internal Medicine Foundation: What is medical professionalism?, 2019, https:// www.abimfoundation.org/what-we-do/medical-professionalism. 
[38] Construction 2I Steering Committee: Reinventing Construction, Ministry of Manpower and Ministry of National Development, Singapore, 1999.

[39] Construction Industry Development Bord: Construction Industry Transformation Programme (CITP) 2016-20, Kuala Lumpur, 2015.

[40] Nixon, J.: 'Not without dust and heat': the moral bases of the 'new' academic professionalism, British Journal of Educational Studies, 49 (2001) 2, pp. 173-186.

[4I] Orringer, N.: What is 'professionalism' in academics?, ResearchGate, I January 20I4, https://www. researchgate.net/post/What_is_professionalism_in_academics.

[42] Callaway, H.G.:What is academic professionalism? 7 July 20I5, https://www.researchgate.net/post/ What_is_academic_professionalism.

[43] Inter Academy Partnership: Improving Scientific Input to Global Policy Making: with a focus on the UN Sustainable Development Goals, Washington, D.C., 2018.

[44] Korenman, S.G.:Teaching the Responsible Conduct of Research in Humans, University of California at Los Angeles, Los Angeles, CA, 2006.

[45] Foxell, S.: Professionalism for the Built Environment, Routledge, London, 2018.

[46] Designing Buildings Wiki: Fit for Purpose? Big data reveals construction knowledge gap, 2017, https:// www.designingbuildings.co.uk/wiki/Fit_for_purpose_-_Big_data_reveals_the_construction_ knowledge_gap.

[47] National Institute of Environmental Health Sciences: NIEHS Strategic Plan 2018-23,Washington, D.C., 2018.

[48] Stark, P.B.: The new definition of professionalism, 9 March 20I5, https://peterstark.com/definition-ofprofessionalism/.

[49] Lord Benson: Criteria for a group to be considered a profession, Hansard (Lords), 8 July 1992, pp. 1206-1207. 